\title{
Service Blueprinting: An Effective Approach for Targeting Critical Service Processes - With a Case Study in a Four-Star International Hotel
}

\author{
Arash Shahin \\ Department of Management, University of Isfahan \\ Hezar Jarib St., Isfahan 81746-73441, Iran \\ Tel: 98-311-793-2040Ｅ-mail: arashshahin@hotmail.com
}

\begin{abstract}
While techniques such as service blueprinting has been used mostly for analysis of a single service process, its application in targeting and selecting critical service processes have not been addressed in the literature. In this paper, the subject of service blueprinting has been demonstrated and applied in targeting critical processes of the front desk encounter of a four star international hotel. It has been found that among the five mapped processes, the check-in service is targeted as critical and suitable for further analysis and as the first priority for improvement.
\end{abstract}

Keywords: Blueprinting, Critical, Hotel, Process, Service 


\section{Introduction}

Along with the awakening to the domination of services in the world's economies, there is a growing emphasis in business practice on creating meaningful, memorable customer experiences (Meyer and Schwager, 2007). The importance of customer experience management is not only being touted in consumer markets, but also in business-to-business contexts where research shows meaningful customer experiences and the resulting emotional bonds between customers and suppliers are more important than rational motivations in creating customer loyalty (Crosby and Johnson, 2007). It is important to note that a recent comprehensive review of the academic literature on product innovation also reveals little explicit coverage of research on service innovation (Hauser et al., 2006). In this respect, analysis and redesign of service processes becomes an important subject, particularly in advanced quality management approaches such as Six Sigma in which, its service application toolbox needs further development.

Literature review addresses several service process improvement issues including service failures; failure types and impact, profiling service failures, the link between operational factors and customer outcomes, the link between operational processes and financial outcomes, the impact of system reliability on service recovery, an operational framework for service recovery, process improvement, collecting failure data, and analyzing and interpreting failure data (Johnston and Michel, 2008).

However, the author believes that a good starting point, when designing or redesigning a service process is to perform an operations analysis. An operations analysis is a structured study that (1) identifies each task to be performed and the flow of people and materials through the system, and (2) evaluates the tasks and flows to determine ways in which the process can be simplified and improved. Two simple tools that can guide an operations analysis are a process flow diagram (Jackson et al., 1998; Slack et al., 2001; Markland et al., 1998; Stevenson, 1999; Dilworth, 2000; Juran and Godfrey, 1999) and a process chart (Murdick et al., 1990). Process charts also can be found in most of the production and operations management handbooks. A process flow diagram is an arrow diagram that shows, step by step the sequence in which a service is performed (or a product is produced) and the correct spending movement of materials, people, or information. Flowcharting will demonstrate the relationships and provide the initial preparation of determining who the supplier is and who the customer is. These charts should be prepared for all subsystems in the organization (Gopalakrishnan et al., 1992).

In service applications, a special kind of flowcharting technique, called 'Service Blueprinting' is used. This technique is similar to the regular process mapping approaches with an exception that the front office and back office are separated by differentiation lines, enabling the analyzer to better investigate the criticality of service on the customer side. Although the technique seems more effective for service applications compared with the common flowcharting approaches, it has not been widely employed. Some of the few recent investigations include Akamavi (2005) who used service blueprinting for improving the process of opening a student bank account at the Lloyds TSB at a local branch. Kumar and 
Steinebach (2008) presented a closed-loop mistake-proof operation system for surgery processes that would likely eliminate preventable medical errors. The design method used was a combination of creating a service blueprint, implementing the six sigma DMAIC cycle, developing cause-and-effect diagrams as well as devising poka-yokes in order to develop a robust surgery operation process for a typical US hospital. They found that implementing service blueprint along with the poka-yokes, will likely result in the current medical error rate to significantly improve to the six-sigma level. Kumar et al. (2010) used service blueprinting together with Six Sigma DMAIC cycle, cause-and-effect diagrams and Poka-yokes to modify the existing service blueprint to improve the operational process of one online business, Bellacor. They found that implementing their new proposed blueprint will likely result in improved customer service, improved delivery tracking, fewer errors and a better overall experience for the customer.

Considering the literature, it seems that while techniques such as service blueprinting has been used mostly for analysis of a single service process, its application in targeting and selecting critical service processes have not been addressed in the literature. Therefore, the main question in this paper is to address hoe such technique could be used for analysis of a number of service processes in order to target the most critical one. For this purpose, in the following the subject of service blueprinting is demonstrated. It is then applied in targeting critical processes of the front desk encounter of a four star international hotel in Iran.

\section{Service blueprinting}

A special kind of flow-chart is called service blueprint, which also includes the line of visibility, between customers and service provider. In other words, in service blueprinting, the line of visibility separates activities of the front office, where customers obtain tangible evidence of the service, from those of the back office, which is out of the customers' view. The high and low contact parts of the service delivery process are kept physically separate, but they remain linked by communications. This separation highlights the need to give special attention to operations above the line of visibility, where customer perceptions of the service's effectiveness are formed. Designing an efficient process is the goal of the back office, but the back office operations have an indirect effect on the customer because of delays and errors. The blueprinting exercise also gives managers the opportunity to identify potential fail points and to design foolproof (Poka-Yoke is the term borrowed from Japan) procedures to avoid their occurrence, thus ensuring the delivery of high quality service (Fitzsimmons and Fitzsimmons, 1999).

A process chart gives a more detailed breakdown of the process into tasks, and it classifies each activity as being either a processing operation, a movement, an inspection, a delay, or a storage. All those charts can be based on an existing process for a redesign or a tentative design for a new process (Martinich, 1997). Service blueprinting is chosen as the most popular and useful tool for service operations analysis. This type of analysis not only can lead to the elimination of tasks, reduction movements, and simplification of work, but it can also help to identify opportunities to create work cells or to use more efficient flow processing for some set of activities. This tool also provides an excellent communication device for 
visualizing and understanding the service operation. Shostack $(1984 ; 1987)$ was the one who first suggested service blue printing for service process analysis. He showed how the service process could be modified by using service blueprinting for a typical shoe repair service and a discount brokerage service. He proposed a four steps approach for designing a blueprint as:

(1) Identifying processes of service delivery and present them in a diagrammatic form. The level of details will depend on the complexity and nature of the service.

(2) Identify the fail points. These are stages where things might go wrong. The actions necessary to correct these must be determined, and systems and procedures developed to reduce the likelihood of them occurring in the first instance.

(3) Establishing time frame. Set standards against which the performance of the various steps might be measured. Frequently, this is the time taken.

(4) Analyzing the profitability of the service delivered, in terms of the number of customers served during a period of time.

He also defined a list of benefits about using service blueprinting, while a more completed list of benefits is given by Martinich (1997) as follows:

(1) The visual representation makes it easier to determine which activities are truly necessary, which can be deleted, and which can be modified.

(2) Customer contact points are clearly identified. This helps to point out activities that can be performed separately and where opportunities for co processing of activities exist.

(3) Likely service failure points are identified. This is helpful in developing plans to minimize the chance of a failure and in identifying possible corrective actions, if failure does occur.

(4) The service blueprint is an excellent tool for training workers. They can see what activities must be performed and how; where failures are most likely to occur and how to prevent and correct them.

(5) The blueprint is useful for identifying the equipment and materials needed and how the service facilities should be spatially arranged to facilitate the services.

(6) Service blueprints can be reconstructed regularly and used to evaluate and improve the service system over time, especially as new technologies become available and the services provided by the system change or expand.

Lovelock and Van der Merwe (1999) showed the application of service blueprinting in a hotel visit, a bank service, and a florist service. Their blueprints were not so completed and only addressed the flow of materials and service packages. Other researchers like Lovelock and Van der Merwe (1999), Meredith (1992), Noori and Radford (1995), Melnyk and Denzler (1996), Hope and Muhlemann (1997), Chase et al.(1998), and Haksever (2000) used service blueprinting in a very simple form and less useful. More completed forms of service blueprinting applications can be obtained from Martinich (1997), who described the use of 


\section{Macrothink

blueprinting in a dry-cleaning store, and Senior and Akehurst (1990), who developed a new approach, called 'perceptual blueprinting technique'. The latter technique was formulated during a study of service quality in the UK roadside lodge sector using the principles of 'soft systems methodology', 'service blueprinting', and 'perceptual gap analysis'. Their model involved three stages: (1) Mapping stage, (2) Questionnaire stage, and (3) Analysis stage. An example of the service map for the meal service component of a typical hotel is suggested by Randall (1993) as illustrated in Figure 1.

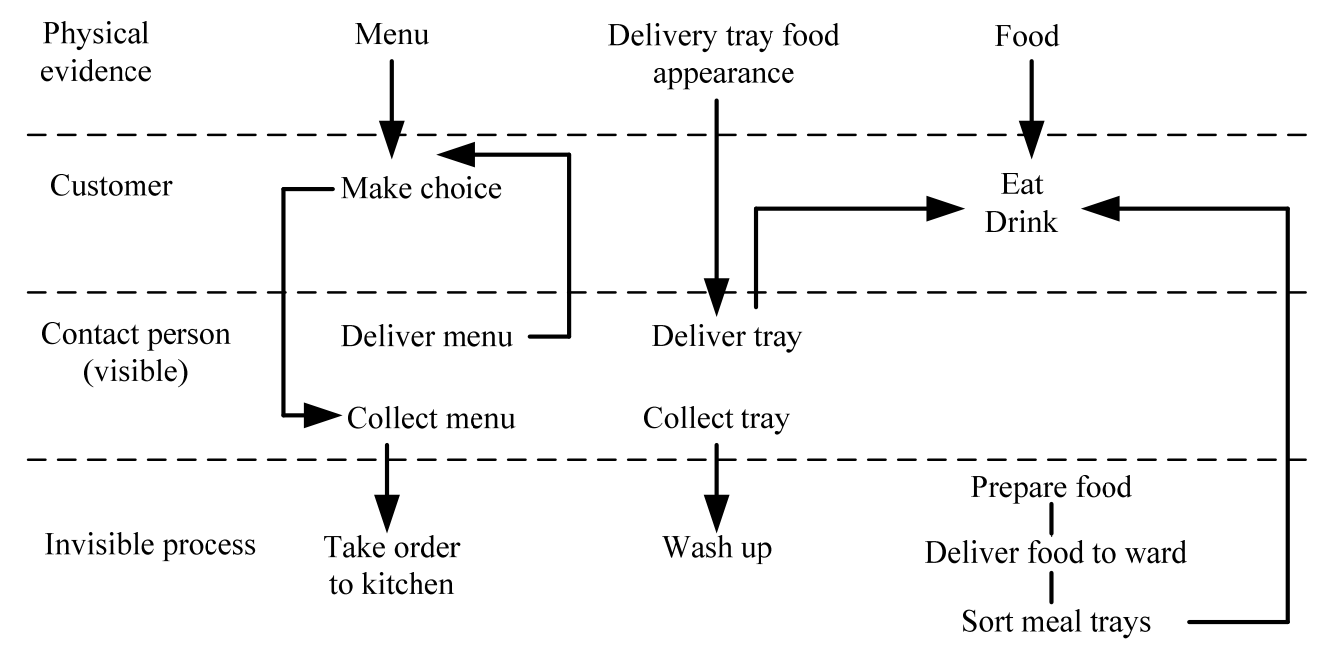

Figure 1. A service map for the meal service component of a typical hotel (Randall, 1993).

This is a simple example, showing only the most basic steps involved in the process. The map may be read horizontally from left to right to understand the actions or steps that must be performed by either the customer or the contact employees, or it may be read vertically to understand the structural relationships that exist to support the actions of the customers and employees. Also a typical form of service blueprinting is presented in Figure 2. Kunst and Lemmink (1992) compared service mapping and service blueprinting. The result of their comparison is listed in Table 1. According to this type of comparison, both techniques are valuable and relevant for service process analysis. 


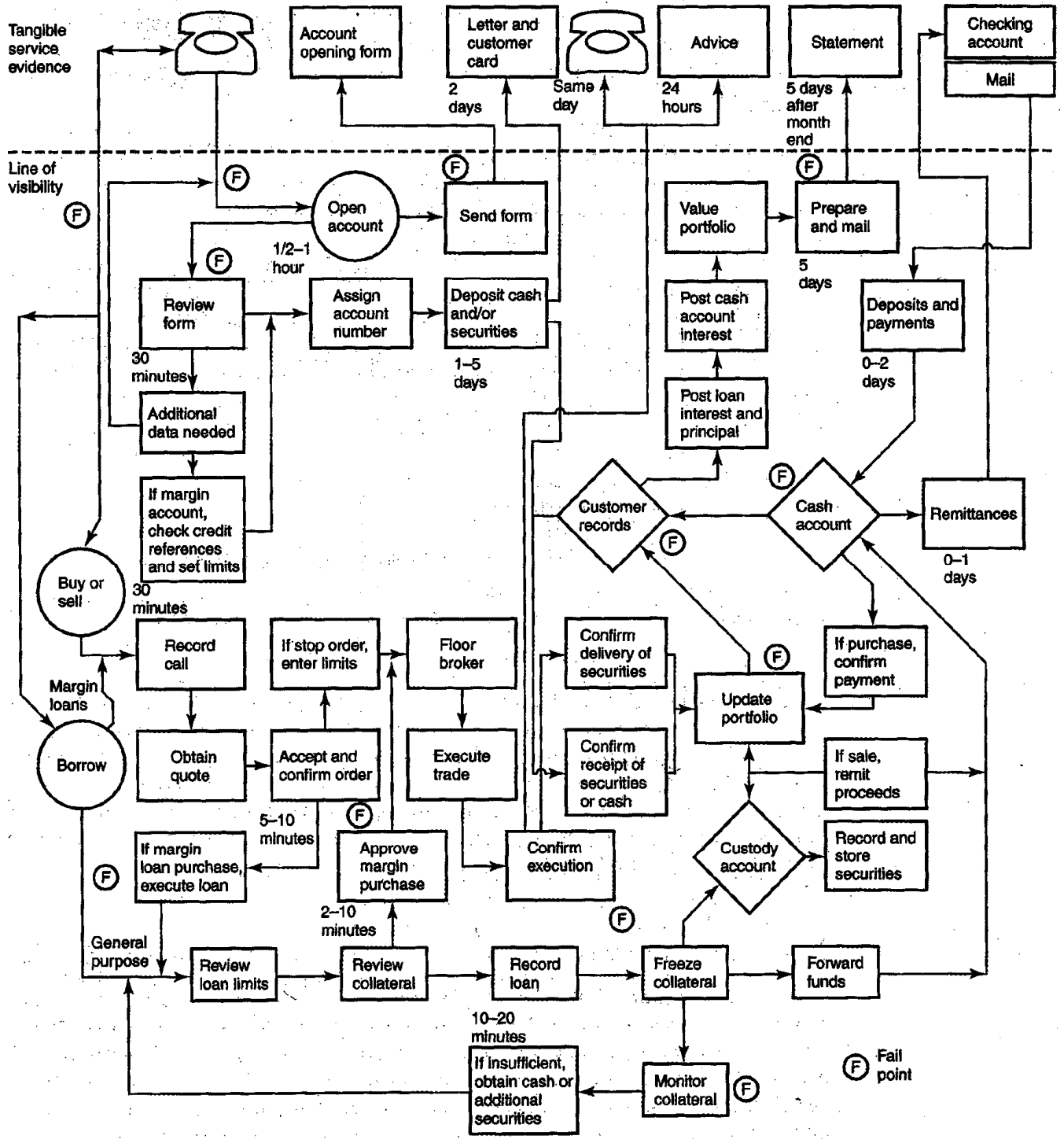

Figure 2. A service blueprinting for discount brokerage service (Shostack, 1984; Haksever, 2000).

As it is shown, service mapping consists of different areas such as: customer, service provider, support functions, and management functions. What separate each of these areas are line of interaction, line of visibility, line of internal interaction, and line of implementation, respectively (Lovelock, 1992). Lovelock also presented an example of service system management, which was a combination of both service blueprinting and service mapping. 


\section{Macrothink}

Table 1. Differences and similarities between service blueprinting and service mapping (Kunst and Lemmink, 1992).

\begin{tabular}{ll}
\hline Service blueprinting & Service mapping \\
\hline $\begin{array}{l}\text { (1) Primary an engineering paradigm } \\
\text { (2) Organizational structure not }\end{array}$ & $\begin{array}{l}\text { (1) More of a psychological paradigm } \\
\text { specifically included }\end{array}$ \\
$\begin{array}{l}\text { (3) Physical products included in a } \\
\text { included }\end{array}$ & (3) Physical products not included \\
(4) Fail points are identified & (4) Fail points are identified \\
(5) Line of visibility identified & (5) Line of visibility identified \\
(6) Line of interaction not shown & (6) Line of interaction shown \\
(7) Line of implementation not shown & (7) Line of implementation shown \\
(8) Time and cost partly referred to & (8) Time and cost not reffered to \\
(9) Comments to each service element & (9) Comment to each service element \\
not systematically presented & systematically presented (service \\
(10) Not related to quality dimensions & (10)Partly related to quality dimensions \\
\hline
\end{tabular}

Service blueprinting shares similarities with other process modeling approaches in that it 1) is a visual notation for depicting business processes via symbols that represent actors and activities, 2) can be used to represent high-level overviews of conceptual processes or details of particular support or subprocesses, and 3) will accommodate links to parallel and sub-process documents and diagrams via other more internally-focused process modeling tools and languages such as BPMN (Business Process Modeling Notation) and UML (Unified Modeling Language). However, service blueprinting is not as complex or as formal as some business process modeling tools such as UML (Siau and Loo, 2006).

In the following, a selected set of symbols are suggested for service blueprinting.

\section{Symbols used for service blueprinting}

A new comprehensive set of symbols (Figure 3) is compiled following a review of the literature and all samples of service blueprinting and service mapping. Appropriate symbols can be selected from this set with respect to suitability and applicability in customizing the application of service blueprinting in particular service processes. 


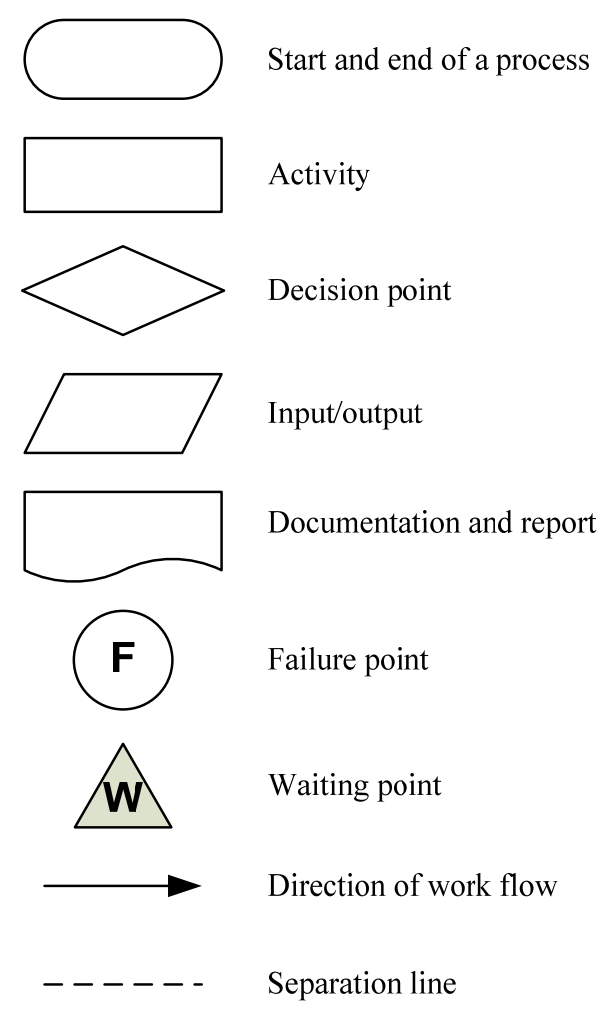

Figure 3. A proposed set of symbols for service blueprinting and service mapping.

\section{Case study}

The four star international hotel of Ali-Qapu is one of the twenty Azadi International Hotel chain, located on the famous historical street called Chahar-Bagh at convenient distance to historical monuments at the center of Esfahan which is the second major city in Iran with the highest tourism potential in the country. There are 104 members of staff working in the hotel. All the 102 rooms and suites are equipped by central air conditioning system, TV, audio and video central systems, accessibility to satellite programs, room service and wake up call. Ali-Qapu was established 36 years ago. The total area of the hotel is about 7500 square meters with six stories. Before eleventh of September 2001, the hotel room occupied rate was about 76\% (50\% Iranian guests and 26\% international tourists).

Out of 20 service encounters, the front desk is selected for service blueprinting. The blueprints of the five different service processes at this encounter are presented in Figures 4 to 8 . The symbols used for denoting the operations are derived from Figure 3. 


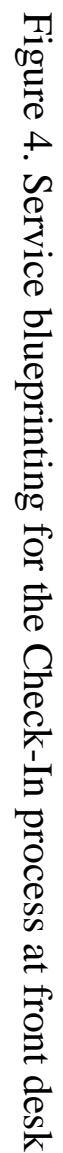
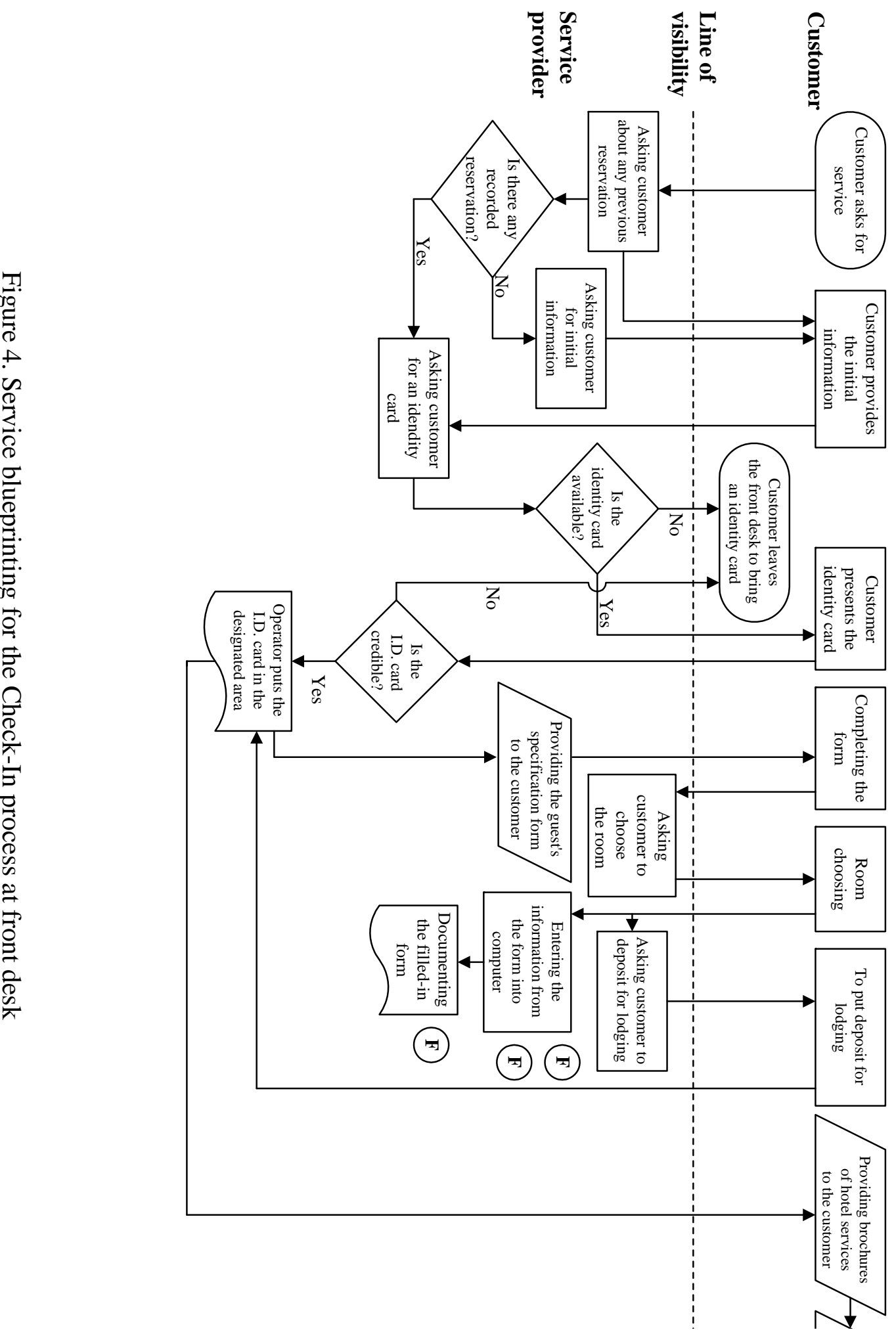


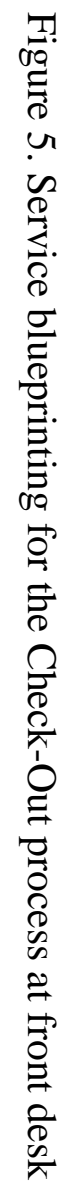

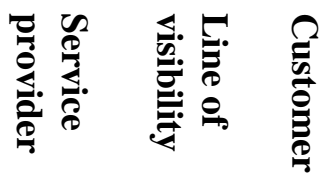

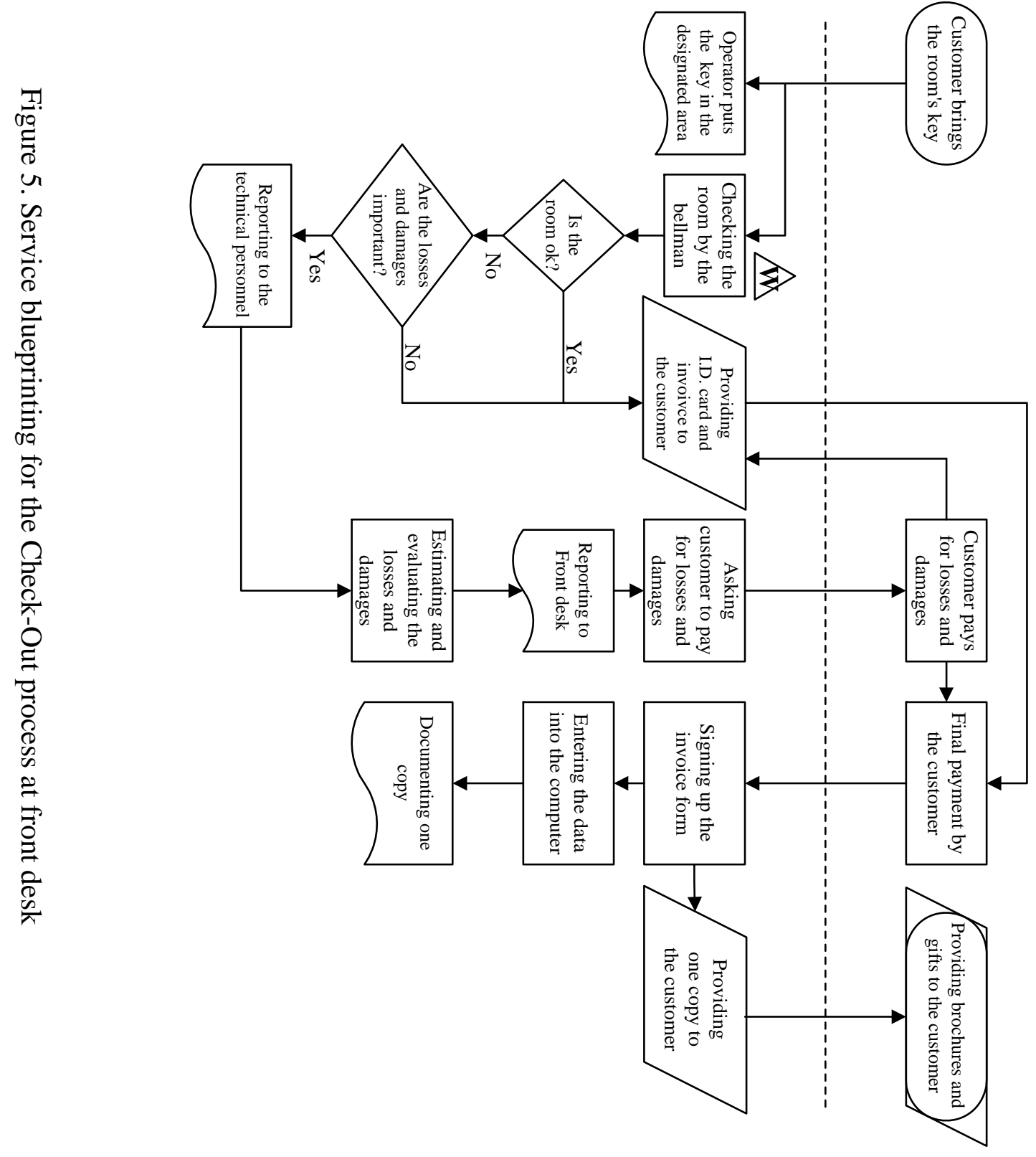




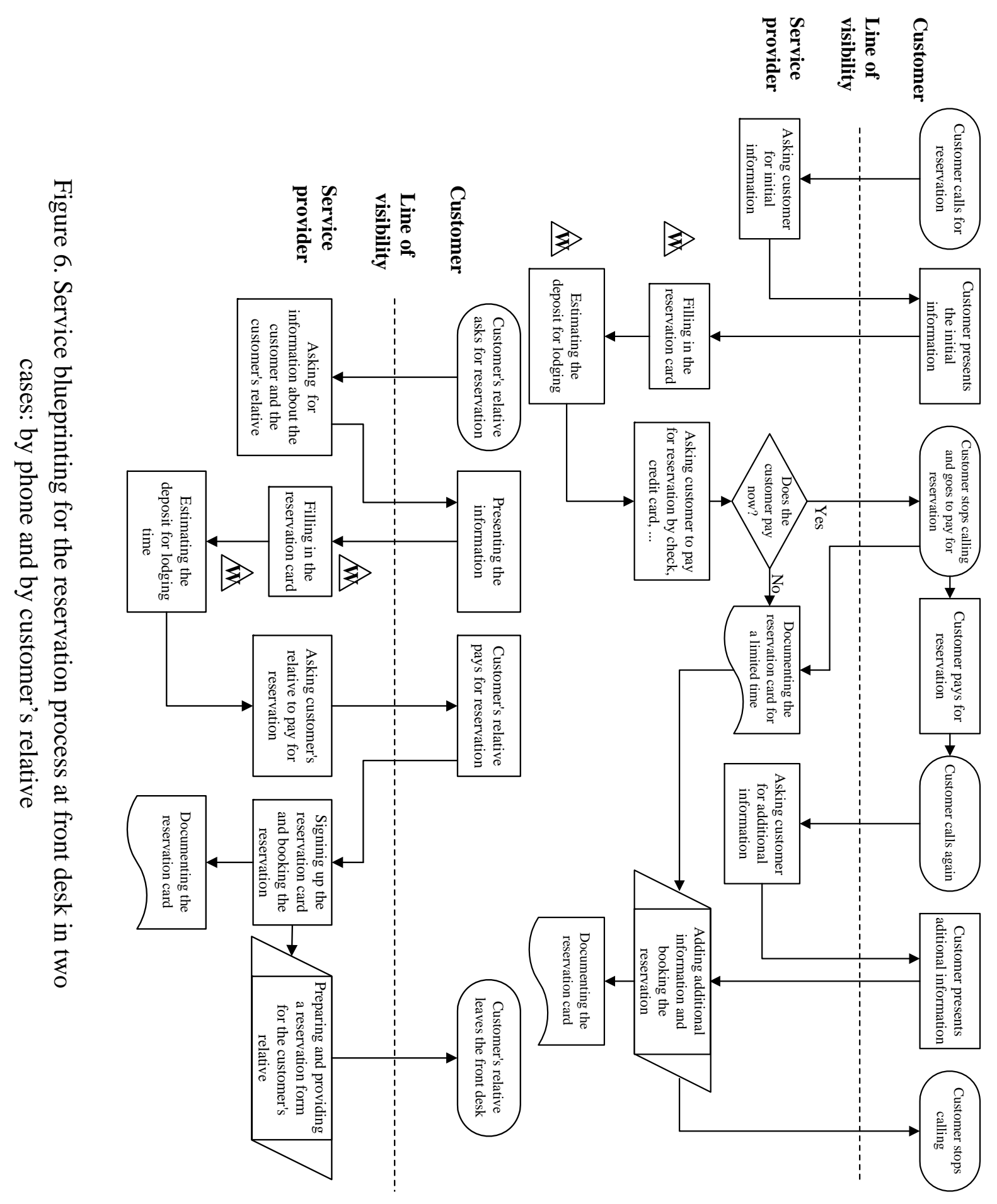




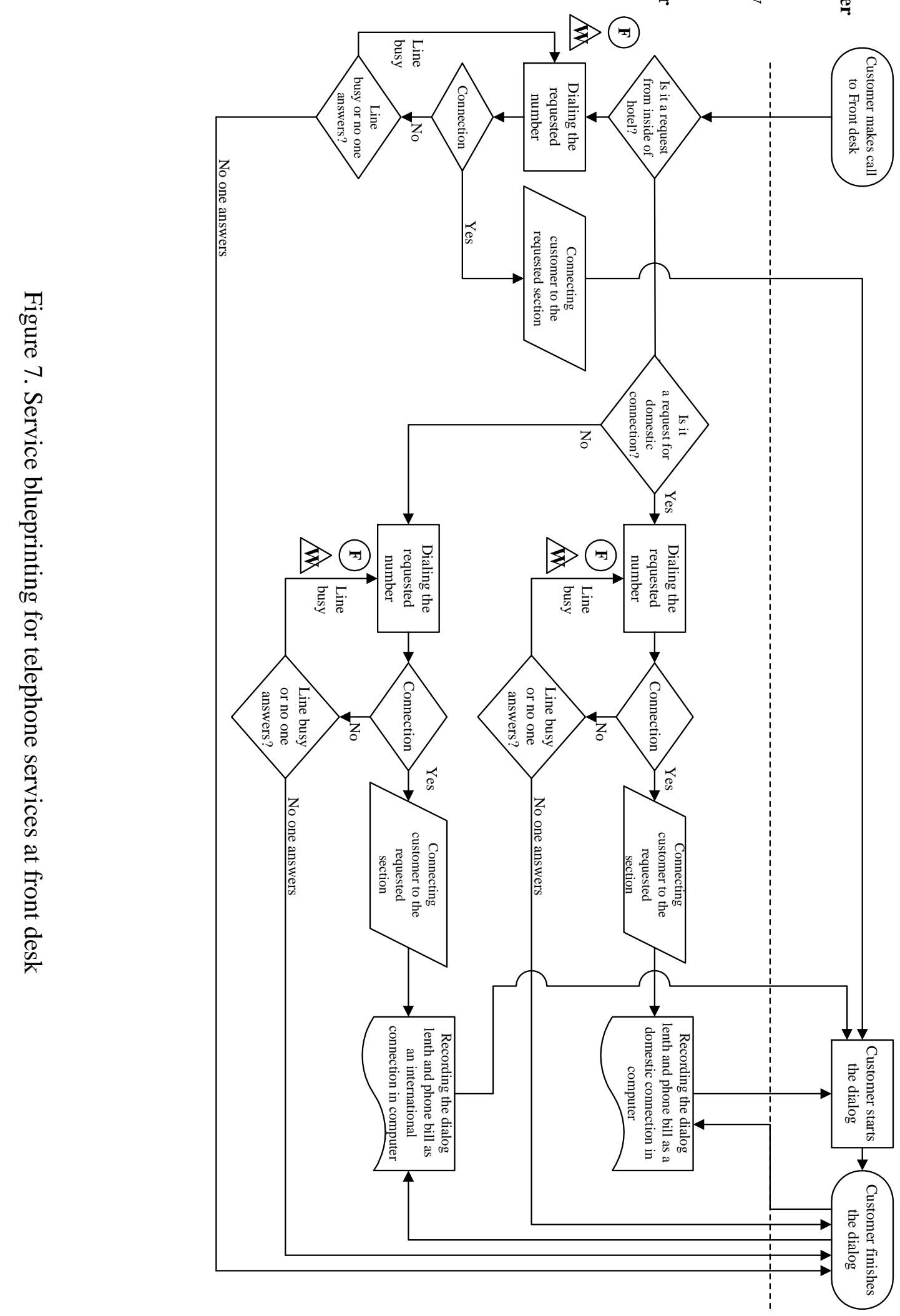




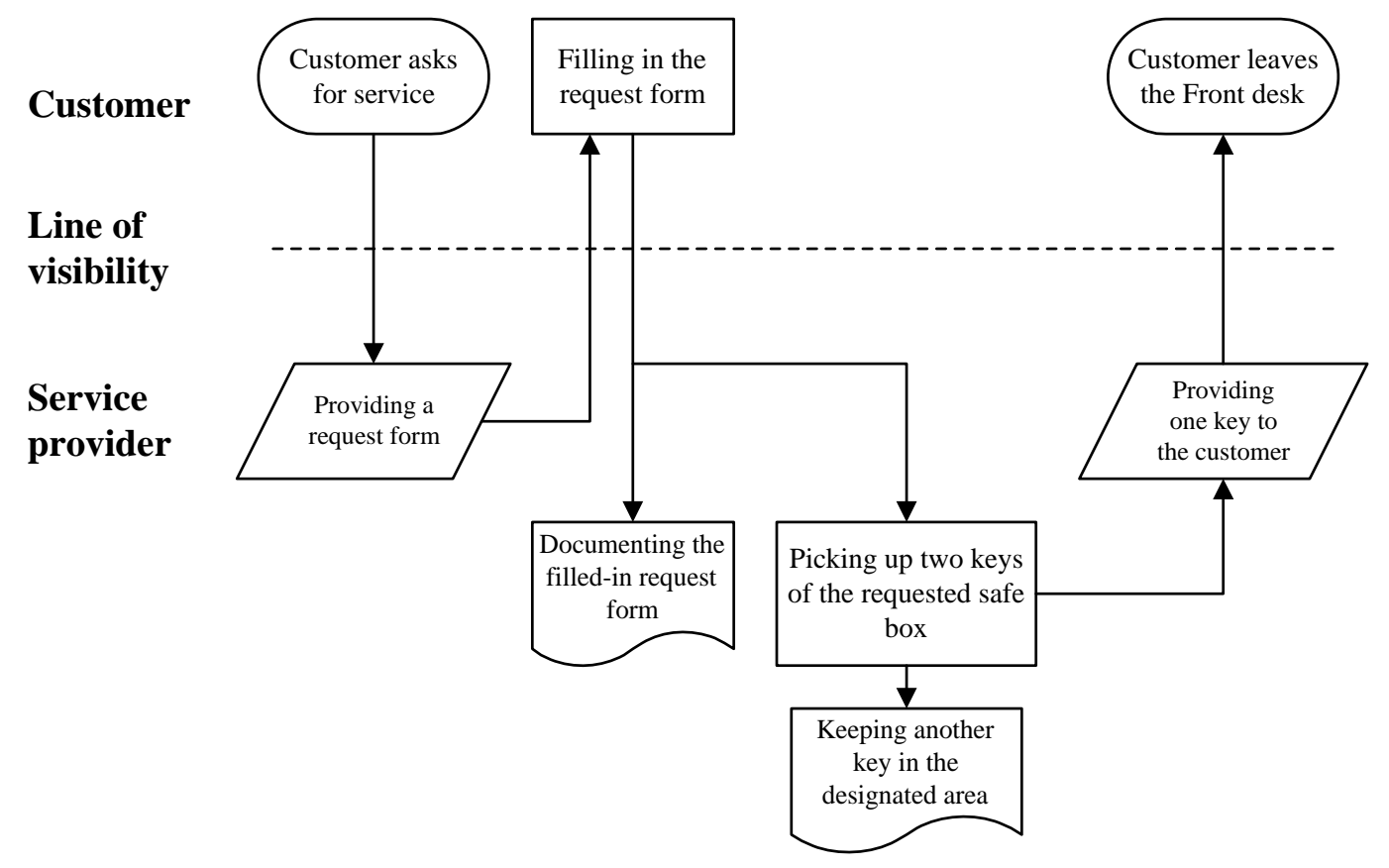

Figure 8. Service blueprinting for Safe Box service at front desk.

\section{Discussion and Conclusions}

Service processes have a number of characteristics, which the managers must understand, since they define the competitive environment of service processes. The general characteristics and requirements of service processes can be categorized according to several schemes. Quite often, authors have developed their own set of service process characteristics best suited to the specific topic they want to deal with in services design. This implies that a common opinion on which characteristics should be considered for classifying service processes does not exist yet (Kasper et al., 1999). Selecting those characteristics depends on the nature of the SE and the quality strategies of managers. A relatively comprehensive set of characteristics have been suggested by Shahin and Jamshidian (2006) for differentiating and targeting service encounters. They include 1) extent of contact; 2) labour intensity; 3) interaction; 4) customization; 5) complexity of service; 6) nature of service act; 7) recipient of act; 8) profit or non profit; 9) internal and external services; and 10) The physical site of the service delivery.

The service blueprints show that the level of customer involvement and interaction, labour intensity, and complexity in the Check-In services seem to be relatively higher than in the other services provided at front desk. Therefore, the Check-In process is targeted and addressed as critical. However, based on the research outcomes this advantage is added by this paper to those addressed in the literature that service blueprinting not only can be used for analysis of a single process, but also it could be employed for comparison of different service processes and targeting the most critical ones.

As it was emphasized, service blueprinting plays a great role in analyzing service processes and designing a quality service. By reviewing the available literature on subjects such as service blueprinting, service mapping and process flowcharting, some most effective symbols 
were compiled and suggested to be used for analyzing service processes.

Considering the above 10 characteristics addressed by Shahin and Jamshidian (2006) for differentiating and targeting service encounters out of which, only four characteristics are used for analyzing blueprints, it seems future studies could work on service blueprinting in a way that more characteristics could be investigated not only for process targeting, but also for analysis of single service processes. It is important to note that in this investigation only the line of visibility was used to separate customer activities from the service provider. Perhaps using other lines, i.e. line of interaction, line of internal interaction, and line of implementation helps the analyzer to take more advantage out of the 10 addressed characteristics. Also, knowing which of the dominated areas by lines are more important to the managers provides a better basis for analysis and targeting the most critical process. In addition, it should be mentioned that a service organization includes several encounters and in each encounter there exists several processes. The case study only denoted one encounter out of 20 hotel encounters, in which only five relatively simple service processes involved. It seems in complicated cases in which there are delivered more services in an encounter and the processes are typically more complex, service blueprinting becomes difficult and time consuming. On the other hand, like other flowcharting approaches, service blueprinting is limited when documenting detailed processes. When service delivery becomes more complicated, this will naturally increase the complexity of the flowchart, even though large processes can be created on huge diagrams known as brown papers. The difficulty still remains of clearly documenting the process so that the targeted customers can clearly understand the flow of the whole process, and hence understand how the service is delivered. Therefore, it is highly emphasized that such an effective technique should be conducted with care. The technique seems beneficial more in cases of service encounters with limited number of services and with relatively simple processes.

\section{References}

Akamavi, R.K. (2005). Re-engineering service quality process mapping: e-banking process. International Journal of Bank Marketing, 23(1), 28-53.

Chase, R.B., Aquilano, N.J., \& Jacobs, F.R. (1998). Production and operations management - manufacturing and services. (8th ed.). New York: Irwin/McGraw-Hill.

Crosby, L.A., \& Johnson, S.L. (2007). Experience Required. Marketing Management, 16(4), 20-28.

Dilworth, J.B. (2000). Operations management - providing value in goods and services. (3rd ed.). New York: The Dryden Press, Harcourt college publishers.

Fitzsimmons, J.A., \& Fitzsimmons, M.J. (1999). Service management - operations, strategy, and information technology. (2nd ed.). New York: Irwin/Mc Graw-Hill.

Gopalakrishnan, K.N., McIntyre, B.E., \& Sprague, J.C. (1992). Implementing internal quality improvement with the house of quality. Quality progress, September, 57-60.

Haksever, C. (2000). Service management and operations. New York: Prentice-Hall Inc. 


\section{Macrothink}

Journal of Management Research ISSN 1941-899X 2010, Vol. 2, No. 2: E9

Hauser, J., Tellis, G.J., \& Griffin, A. (2006). Research on Innovation: A Review and Agenda for Marketing Science. Marketing Science, 25 (November/December), 687-721.

Hope, Ch., \& Muhlemann, A. (1997). Service operations management - strategy, design and delivery. Oxford: Prentice Hall Europe.

Jackson, J.R., Harry, K., \& Frigon, N.L. (1998). Fulfilling customer needs - A practical guide to capacity management. New York: John Wiley \& Sons.

Johnston, R. \& Michel, S. (2008). Three outcomes of service recovery, customer recovery, process recovery and employee recovery. International Journal of Operations \& Production Management, 28(1), 79-99.

Juran, J.M. \& Godfrey, A.B. (1999). Juran's quality handbook. (5th ed.). New York: McGraw-Hill.

Kasper, H., Helsdingen, P.V., \& DeVries, W. (1999). Service marketing management - An international perspective. New York: John Wiley \& Sons Ltd.

Kumar and Steinebach (2008). Eliminating US hospital medical errors. International Journal of Health Care Quality Assurance, 21(5), 444-471.

Kumar, S., Hudson, B. \& Lowry, J. (2010). Consumer purchase process improvements in e-tailing operations, A case study. International Journal of Productivity \& Performance Management, 59(4), 388-403.

Kunst, P., \& Lemmink, J. (1992). Quality management in services. The Netherlands: Van Corcum \& Comp. B.V.

Lovelock, Ch.H. (1992). Managing services - Marketing, operations, and human resources. (2nd ed.). New York: Prentice-Hall, Inc.

Lovelock, Ch.H., \& Van der Merwe, S. (1999). Services marketing - A European perspective, New York: Prentice-Hall Europe.

Markland, R.E., Vickery, Sh.K., Davis, R.A., \& Sounderpandian, J. (1998). Operations management - concepts in manufacturing and services. (2nd ed.). New York: South-Western College Publishing.

Martinich, J.S. (1997). Production and operations management - An applied modern approach, New York: John Wiley \& Sons, Inc.

Melnyk, S., \& Denzler, D.R. (1996). Operations management: A value-driven approach. New York: Richard D. Irwin, Inc.

Meredith, J.R. (1992). The management of operations - A conceptual emphasis. (4th ed.). New York: John Wiley and Sons, Inc.

Meyer, C., \& Schwager, A. (2007). Understanding Customer Experience. Harvard Business Review, February, 117-126. 


\section{Macrothink}

Journal of Management Research ISSN 1941-899X 2010, Vol. 2, No. 2: E9

Murdick, R.G., Render, B., \& Russell, R.S. (1990). Service operations management, New York: Allyn \& Bacon.

Noori, H., \& Radford, R. (1995). Production and operations management - Total quality and responsiveness. New York: McGraw-Hill, Inc.

Randall, L. (1993). Perceptual blueprinting. Managing Service Quality, May, 7-12.

Senior, M., \& Akehurst, G. (1990). The perceptual blueprinting paradigm. Proceedings of the QUIS II: A symposium on quality in services, Norwalk Connecticut, 8-11 July.

Shahin, A., \& Jamshidian, M. (2005). Service Encounter Selection (SES): An Effective Approach for Targeting Service Encounters. Proceeding of the QMOD 2005: Quality Management for Organizational and Regional Development, Palermo, 29 June - 1 July, 83-91.

Shostack, G.L. (1984). Designing services that deliver. Harvard Business Review, January-February, 133-139.

Shostack, G.L. (1987). Service positioning through structural change. Journal of Marketing, 51(January), 36.

Siau, K., \& Loo, P. (2006). Identifying Difficulties in Learning UML. Information Systems Management, Summer, 43-51.

Slack, N., Chambers, S., \& Johnston, R. (2001). Operations management. (2nd ed.). Oxford: Harlow, Financial Times -Prentice-Hall, Inc.

Stevenson, W.J. (1999). Production/operations management. (6th ed.). New York: Irwin/McGraw-Hill, Inc. 